Український журнал з бібліотекознавства та інформаційних наук. Випуск 3 (2019) Ukrainian Journal on Library and Information Science. Issue 3 (2019)

УДК 004.77:316.77]:316.34-028.63(477)

DOI: https://doi.org/10.31866/2616-7654.3.2019.169673

\section{ЦИФРОВА НЕРІВНІСТЬ У СУЧАСНОМУ СУСПІЛЬСТВІ: УКРАЇНСЬКИЙ ВИМІР СВІТОВИХ ТЕНДЕНЦІЙ}

Тетяна Миськевич, молодший науковий співробітник відділу обслуговування інформаційними ресурсами Національної юридичної бібліотеки

Національної бібліотеки України імені В. І. Вернадського (Київ, Україна) e-mail: Mizkevich83@gmail.com ORCID: https://orcid.org/0000-0002-2324-6869

Сьогодні повсюдна інформатизація стає необхідною передумовою подальшого суспільного розвитку. Утім, її макросоціальний перетворюючий ефект пов'язаний не тільки 3 новими перевагами та можливостями в різних сферах життєдіяльності, а й із низкою модернізаційних ризиків та загроз для сталого розвитку. Суперечливий характер процесу глобальної інформатизації актуалізує завдання осмислення однієї з основних і пріоритетних для вирішення світових соціальних проблем - явища цифрової нерівності.

Стаття присвячена висвітленню специфіки проблеми цифрової нерівності в сучасному суспільстві, визначенню поточної комплексної оцінки ступеня її актуальності для України. Цифрова нерівність розглядається як динамічна загроза, що одночасно поширюється на глобальному, регіональному та локальному рівнях. Охарактеризовано основні фактори виникнення дисбалансу в освоєнні цифрового простору в Україні, а також його актуальні показники.

Оскільки цифрова нерівність являє собою складний та багатоаспектний феномен, дане дослідження грунтується на застосуванні комплексного підходу, що передбачає врахування еволюції цифрової нерівності та виокремлення у зв’язку з цим двох етапів її розгортання. Для визначення ситуації з цифровою нерівністю в Україні використовувалися методи статистичного дослідження та моніторингу, що дало змогу з'ясувати стан локальної цифрової нерівності та динаміку ключових показників України щодо рівня розвитку інформаційного суспільства у даних світових рейтингів.

Виявлено, що Україна все ще залишається країною $з$ наздоганяючою інформатизацією, для якої характерне одночасне розгортання обох етапів цифрової нерівності. Запропоновано пріоритетні напрями з мінімізації деструктивних проявів цифрової нерівності.

Ключові слова: цифрова нерівність, рівні цифрової нерівності, фактори поширення цифрової нерівності, інформаційно-комунікаційні технології, ІКТ, інформатизація, цифрова нерівність в Україні, Україна в світових рейтингах.

Сучасний етап становлення глобального інформаційного суспільства відзначається стрімким розвитком технологічних засобів перетворення соціальної реальності. Сама категорія технології набуває домінуючого та системоутворюючого значення, позаяк у процесі розвитку соціуму вона виявляється включеною в систему суспільних відносин, впливаючи на різноманітні соціальні структури та підсистеми суспільства (Удовик, 2010, с. 1). Зокрема, новітні інформаційні технології успішно долають такі обмеження попередніх форм комунікативної взаємодії, як недовговічність та повільне розповсюдження інформації, принципово змінюючи при цьому комунікаційну структуру суспільства. Віртуальна реальність, мобіль- 
на телефонія та мережа інтернет роблять умовними кордони, що відокремлюють людей один від одного, мінімізують географічні обмеження, створюють можливості для глобальних комунікаційних процесів.

Сьогодні повсюдна інформатизація стає необхідною передумовою подальшого розвитку людства та одним з основних факторів, що визначають його перспективи. При цьому не можна заперечувати, що поряд із новими перевагами та можливостями, спричиненими революційними зрушеннями в інформаційних технологіях, сучасне суспільство отримало й низку модернізаційних викликів, дослідження яких привертає увагу науковців із різних галузей соціогуманітаристики. Окремі аспекти впливу безпрецедентного та динамічного технологічного прогресу на соціальне буття розглядаються у працях В. Ємеліна (2016), Ю. Зубка (2017), А. Кузнецової (2016), В. Кутирьова (2015), В. Родіонової (2017), Я. Чарковського (2016), K. Himma (2004), L. Zacher (2017), C. Griffy-Brown (2018), C. Yun (2015) та ін. Науковці відзначають суперечливий характер цифрової технологізації, висвітлюючи іï вплив на інформаційні, економічні, політичні, демографічні, культурні та інші процеси в суспільстві, а також їх неминучу у зв'язку з цим трансформацію. Стає очевидним, що подібний макросоціальний перетворюючий ефект має свої негативні наслідки - дослідники вказують на виникнення технологічних, інформаційних і соціальних ризиків та проблем для сталого розвитку суспільства. Тим часом, їх появу передбачав у своїй роботі «Суспільство ризику» один із засновників найбільш впливової соціологічної концепції інформаційного суспільства У. Бекк ще у 90-х роках XX століття (Beck, 1986).

Моніторинг наукових розвідок останніх років дає змогу зробити висновок про те, що на сьогодні одним із ключових ризиків, спричинених глобальною інформатизацією як на колективному, так і на індивідуальному рівні, продовжує залишатися цифрова нерівність ${ }^{1}$. Вагомий внесок у дослідження специфіки iї генезису, розгортання та подолання зроблено багатьма зарубіжними й вітчизняними вченими, представниками гуманітарних та технічних наук. Зокрема, в контексті соціологічних досліджень цифрову нерівність вивчають $€$. Вартанова (Vartanova, 2009), Г. Вороненкова (2016), В. Шабашев (2016), G. Muschert i M. Ragnedda (2017), G. Goggin (2017) і K. Dobransky (2016), які висвітлюють у своїх працях теоретичні та практичні аспекти нового виду соціальної диференціації як однієї з основних і пріоритетних для вирішення світових соціальних проблем.

У розрізі економічних процесів цифрову нерівність розглядають С. Дятлов і О. Лобанов (2017), F. Cruz-Jesus, T. Oliveira та F. Васао (2018). Дослідники доводять, що зниження темпу економічного розвитку країн корелюється зі зростанням у них рівня цифрової нерівності. Водночас, зважаючи на зростаюче значення новітніх цифрових технологій у процесах суспільно-політичного розвитку, тема цифрової нерівності посідає одне з важливих місць і в сучасних політологічних дослідженнях, у яких визначаються нові геополітичні виклики, пов'язані зі зміною моделі взаємовідносин між країнами-лідерами та країнами, що розвиваються в умовах цифрової нерівності, а також перспективами отримання політичних і військових переваг на міжнародній арені від монополізації передо-

\footnotetext{
${ }^{1}$ Вперше терміносполуку «цифрова нерівність» (англ. Digital divide) було вжито в доповіді Національної телекомунікаційної та інформаційної адміністрації уряду США (1995р.) для характеристики різної можливості доступу американців до інформаційної інфраструктури.
} 
Український журнал з бібліотекознавства та інформаційних наук. Випуск 3 (2019) Ukrainian Journal on Library and Information Science. Issue 3 (2019)

вих IT-технологій (Карелов, 2018; Володенков, 2018; Каратеев, 2018). С. Михальчук (2014), О. Афанасьєва (2015), J. Earl та T. Elliott (2018) зосереджують фокус своєї уваги на негативному впливі цифрової нерівності на процеси становлення інститутів електронної демократії та розвитку громадянського суспільства.

Осмислення цифрової нерівності в рамках філософського дискурсу представлене в роботах М. Дєдюліної (2017) та С. Whyte (2018), в яких аналізуються концептуальні й описові аспекти даного явища. Важливу дискусію щодо ціннісних аспектів та етики цифрових технологій піднімає R. Capurro (2018), розглядаючи цифрову нерівність із точки зору інформаційної етики, яка, на думку дослідника, повинна сприяти усуненню технологічних бар'єрів між інсайдерами та аутсайдерами цифрового простору.

Варто зауважити, що $з$ огляду на дедалі інтенсивніше використання можливостей сучасних інформаційно-комунікаційних технологій (далі - IKT) у галузі медицини та активну розробку технологій мобільної медицини (m-health technologies), віднедавна почали з'являтися зарубіжні наукові публікації, які висвітлюють проблематику цифрової нерівності в контексті питань охорони здоров'я. Йдеться про впровадження у розвинених країнах системи цифрової медицини («Digital medicine» або «eHealth»), що дозволяє здійснювати самоконтроль хвороби або її дистанційний моніторинг, підтримувати зв'язок із надавачами медичних послуг або постачальниками ліків тощо. Дослідники констатують, що цифрова нерівність створює бар'єр для розвитку зазначених нововведень та гальмує підвищення рівня державної системи охорони здоров’я в цілому (Fox, \& Connolly, 2018; Chesser, Burke, Reyes, \& Rohrberg, 2016; Latulippe, Hamel, \& Giroux, 2017; Hong, 2018).

Сьогодні використання цифрового простору в світі не $\epsilon$ пропорційним. Теоретичні узагальнення досліджень явища цифрової нерівності приводять до розуміння її як загрози, що одночасно поширюється на глобальному, регіональному та локальному рівнях - дана географічна характеристика дозволяє зрозуміти масштабність даної проблеми. Кордони глобального рівня цифрової нерівності практично збігаються з межами економічно розвинених регіонів (Північна Америка, Західна Європа, розвинені країни Південно-Східної Азії) та країн «третього світу» (Африка, Азія, Південна Америка). Водночас, ряд дослідників відзначають, що на глобальному рівні цифрова нерівність часто поділяє світ на Північ і Південь із «північними» багатими націями та «південними» бідними (Hongladarom, 2007). Наприклад, кількість підключень до мережі, приміром, у одному Нью-Йорку або Токіо більша, ніж у всій континентальній Африці, а у Фінляндії - більша, ніж у Латинській Америці та країнах Карибського басейну разом узятих. Даний рівень показово ілюструється картою цифрової нерівності «Mapping the Digital Divide» ("Global Digital Divide", 2019). Регіональний рівень цифрової нерівності - це поділ на рівні країн, визначальним критерієм якого є рівень розвитку процесу інформатизації та використання IKT, адже в наш час саме основні показники розвитку IKT «стають тим фокусом, що зводить воєдино найважливіші параметри суспільного прогресу, концентровано відображаючи сучасний стан економіки та техніки» (Вартанова, 2000). Регіональний рівень цифрової нерівності обумовлюється відмінностями в науково-технічному та економічному потенціалі різних країн, рівнем розвитку в них освіти, а також ступенем розуміння ними основних тен- 
денцій розвитку сучасної цивілізації. Так, країни-виробники технологій і знань розвиваються за рахунок розбудови власної інформаційної інфраструктури, тоді як іншим залишається роль сировинних придатків або плацдармів для розміщення шкідливих виробництв. До прикладу, яскравий контраст демонструє кордон США та Мексики уздовж річки Ріо-Гранде.

Тривожною особливістю нинішнього стану явища цифрової нерівності $є$ те, що поки не спостерігається ознак реального подолання гігантської прірви між країнами-лідерами розвитку інформаційних технологій та країнами-аутсайдерами. Навпаки, цей розрив із часом тільки посилюється (Ржевська, 2010). Нерівність умов доступу до інформаційного ринку та до можливостей використання сучасних IKT всередині країн стає однією з основних причин виникнення локальної цифрової нерівності. Як приклад держав із локальною цифровою нерівністю можна навести Китай, де, зокрема, райони Пекіна, Шанхая та регіон дельти річки Чжуцзян різко контрастують з іншими регіонами країни.

Проблема цифрової нерівності негативно позначається і на розвитку України, стаючи перепоною на шляху побудови інформаційного суспільства.

В аспекті вивчення цифрової нерівності в Україні варто відзначити публікації таких науковців, як О. Аніщенко, Л. Городенко, О. Єршова, Г. Чмерук і В. Краліч, які провели аналіз стану цифрової економіки в Україні за допомогою індексу цифрових трансформацій GCI (Чмерук, 2018), дослідили наявність інформаційної та цифрової нерівності в українському сегменті мережевих комунікацій (Єршова, 2016), акцентували актуальність для України мовного аспекту цифрової нерівності (Городенко, 2012), висвітлили освітні механізми подолання цифрової нерівності та формування інформаційної культури особистості (Аніщенко, 2012).

Враховуючи той факт, що багатоаспектна проблема цифрової нерівності $є$ не тільки глобальною, а й, що важливо, динамічною, доцільною видається поточна комплексна оцінка ступеня актуальності цифрової нерівності для України. Тому, метою статті є визначення специфіки прояву загальносвітових тенденцій цифрової нерівності в Україні, що передбачає визначення на основі аналізу наявного теоретичного доробку провідних світових тенденцій у проявах проблеми цифрової нерівності, зміни ключових показників України в даних світових рейтингів щодо рівня розвитку інформаційного суспільства, пріоритетних напрямів подолання наявних факторів виникнення дисбалансу в освоєнні цифрового простору в Україні, пов’язаних зі специфікою розгортання цифрової нерівності в сучасних умовах.

Джерелами для аналізу стали міжнародні рейтинги Networked Readiness Index (за період із 2012 по 2016 pp.), Global Innovation Index (за період із 2014 по 2018 pp.) та UN E-Government Survey (за період із 2010 по 2018 рр.), аналітичні матеріали Національного інституту стратегічних досліджень України, інформація 3MI, а також дані Звіту Всесвітнього економічного форуму та Національної доповіді «Цілі Сталого Розвитку: Україна».

Явище цифрової нерівності концептуалізується як форма соціальної стратифікації, що проявляється у диспропорції доступу та використання сучасних IKT. Сьогодні ІКТ розглядаються як один із важливих елементів соціальної інфраструктури та частини системи життєзабезпечення будь-якого населеного пункту - відсутність доступу до IКТ тягне за собою унеможливлення ефектив- 
Український журнал з бібліотекознавства та інформаційних наук. Випуск 3 (2019) Ukrainian Journal on Library and Information Science. Issue 3 (2019)

ного повноцінного функціонування навчальних, лікувальних та інших закладів культурно-побутового призначення. Об'єкти електрозв'язку традиційно та законодавчо відносяться до об'єктів життєзабезпечення, а в сучасному розумінні об’єкти електрозв'язку - це, передусім, інфраструктура широкосмугових дротових і бездротових мереж зв’язку. При цьому, на відміну від систем водо- та електропостачання, а також наземного дорожнього сполучення, інформаційні ресурси неможливо замінити тимчасовими альтернативними рішеннями (Гайнанов, \& Шарифьянов, 2014, с. 3).

Більше того, новітні ІКТ можуть одночасно розглядатися і як ресурс, і як середовище соціального розвитку людини. Їх активне використання стає необхідною передумовою повноцінного функціонування особистості в сучасних умовах, оскільки якість включення населення до економічного, політичного та культурного життя суспільства залежить від можливостей доступу до новітніх IKT. Проте в наші дні значна кількість людей досі не $є$ включеними в нову модель технократичного соціуму через відсутність у них можливості вільного доступу до IKT. Зазначимо, що в нашому дослідженні подібна диференціація за рівнем технологічної доступності є основою цифрової нерівності та відповідає першому етапу розгортання даної проблеми в сучасному суспільстві.

Дисбаланс в освоєнні цифрового простору всередині України пояснюється, в основному, проблемами, пов'язаними з незадовільним матеріальним становищем, а також загальними проблемами телекомунікаційної інфраструктури в окремих населених пунктах країни. Люди 3 низькими статками не можуть повноцінно інтегруватися в сучасний цифровий простір або мають ризик виключення з нього - йдеться або про відсутність технологій, або про їх якість та можливості вчасного оновлення. Так, за даними загальнонаціонального соціологічного дослідження, організованого Соціологічною асоціацією України у 2017 році у 24 областях України та м. Києві, 27 \% опитаних не мають техніки для застосування комп’ютерних технологій (Бакіров, 2017, с. 6).

На жаль, Україна кілька років поспіль входить до десятки найбідніших країн світу (Jamrisko, \& Saraiva, 2018). Принаймні половина працюючого населення України має низькі заробітки. Водночас надзвичайні для країни масштаби внутрішнього переміщення також спричинили поширення бідності або вразливості до неї: 36 млн мешканців зони АТО і прилеглих територій понад 5 млн потрапили або до групи раптово збіднілих, або до групи вразливих до бідності незалежно від того, переїхали вони в іншу частину країни чи залишилися в місці постійного проживання. Динаміка збільшення частки витрат на харчування й оплату житлово-комунальних послуг українців також свідчить про загальне зниження життєвого рівня та негативні структурні трансформації у споживанні переважної більшості сімей ("Цілі сталого розвитку", 2017).

Зазначимо, також, що в Україні спостерігається тенденція до збільшення масштабів бідності зі зменшенням розміру населеного пункту (Там само), що корелюється з виникненням цифрової нерівності між мегаполісами, промислово розвиненими містами з їх високошвидкісними магістралями та невеликими населеними пунктами, зокрема сільською місцевістю - соціально-замкнутою периферією з меншими інформаційними та економічними можливостями, де населення здебільшого не відчуває на собі позитивного впливу технологічної 
революції. На жаль, із цієї причини «в нашій країні у соціальному та інтелектуальному плані співіснують як “модерні”, так і “постмодерні” сегменти, поняття й цінності індустріальної і постіндустріальної (інформаційної) доби» ("Питання розвитку", 2019) - 35 \% сільського населення, а також 53 \% шкіл, 99 \% медичних закладів в Україні взагалі не мають доступу до швидкого широкосмугового інтернету (Мацегора, 2018).

Саме обмеження телекомунікаційної інфраструктури в окремих населених пунктах країни, зокрема проблеми 3 доступом до широкосмугового інтернету (ШСД), є визначальним фактором, що зумовлює виникнення цифрової нерівності. За офіційними даними, в Україні рівень проникнення ШСД становить лише 11,8 абонента на 100 осіб населення (у сусідніх Словаччині - це 23,3; Угорщині 27,4; а в Білорусі - 31,4). За даними звіту «Digitalin 2018» Міжнародного агентства «We are social», що спеціалізується на дослідженнях у сфері медіа, тільки 58 \% населення країни користуються мережею інтернет. Рівень доступності ШСД в Україні разюче відрізняється у великих містах та сільській місцевості: 28 \% від загальної кількості абонентів проживають у Києві, на решту країни - окрім Київської, Дніпропетровської, Донецької, Одеської, Львівської та Харківської областей припадає менше 40 \% користувачів ("Потенціал розвитку ринку", 2017). При цьому, усього лише 4000 сіл із майже 26000 мають хоча б одного інтернет-провайдера. До слова, статистика демонструє, що практично немає різниці між профілями споживання інтернету сільськими та міськими жителями: згідно з даними найбільшого українського інтернет-провайдера фіксованих ліній «Укртелеком», абоненти, які живуть у містах, у середньому споживають 194 гб трафіку на місяць. $\mathrm{V}$ жителів невеликих населених пунктів, в яких є доступ до мережі інтернет, цей показник становить 165 гб на місяць. При цьому, сценарії споживання інтернету в селі не особливо різняться від споживання в місті - там також дивляться відео 3 YouTube, слухають музику, користуються соціальними мережами та загальнонаціональними сервісами, на кшталт, OLX і Приват24, сплачують послуги on-line тощо. Отже, проблема не у відсутності потреби, а у відсутності можливості ("Цифровое неравенство", 2019).

Щодо можливостей доступу до швидкісного інтернету через мобільні мережі, то, відповідно до даних самих мобільних операторів, більша частина території України не має такого доступу (до уваги бралися дані 3G-покриття від «Київстар», «Vodafone» Україна та «Lifecell»). За словами експертів, на даному етапі розвитку технологій, забезпечення якісним інтернетом тисячі сіл - справа не 3 дешевих, враховуючи ринкові реалії, а тому $3 \mathrm{G}$ та $4 \mathrm{G} \epsilon$ прекрасним рішенням лише для мегаполісів.

Термін «цифрова нерівність» не обов'язково означає відсутність доступу до технологій як таких, це також може означати різницю в технологіях, тому сьогодні, разом зі способом підключення суб'єкта до мережі інтернет (стаціонарне чи мобільне з'єднання), в дослідженнях цифрової нерівності до уваги також беруться показники пропускної здатності для кожної людини (в кбіт / с на душу населення) (див. рис. 1). Так, віднедавна почала визначатися відносна диференціація «між тими, у кого більша або менша пропускна здатність» (Hilbert, 2016), тобто, відмінність у доступній швидкості також містить ознаки цифрової нерівності, оскільки низькошвидкісна інфраструктура не дає 
Український журнал з бібліотекознавства та інформаційних наук. Випуск 3 (2019) Ukrainian Journal on Library and Information Science. Issue 3 (2019)

змоги споживати ряд сучасних сервісів: наприклад, телебачення через мережі передачі даних IPTV, онлайн-трансляції та ігри, імпорт файлів із мережі тощо.

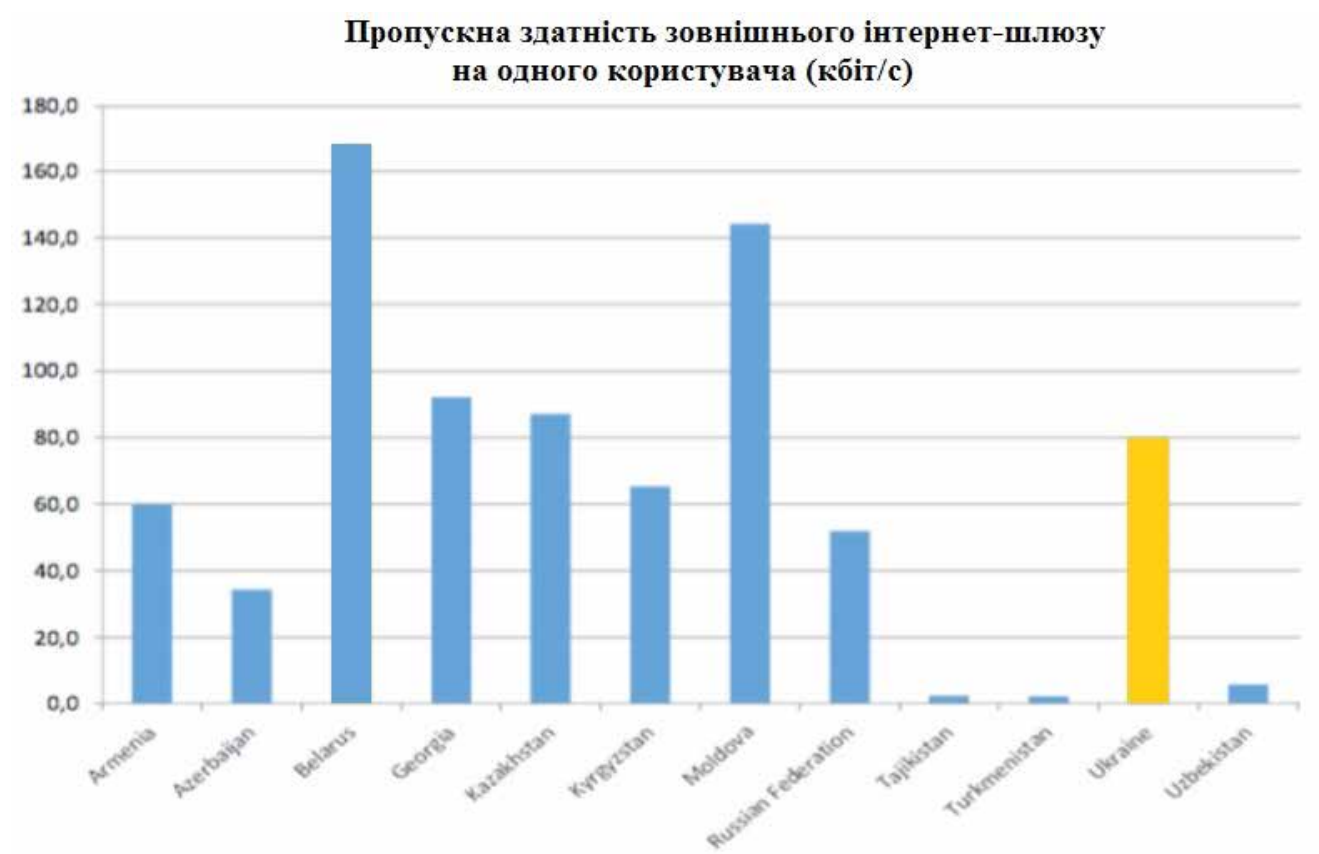

Рисунок 1. Показники України щодо пропускної здатності зовнішнього інтернет-шлюзу на одного користувача. Джерело: International Telecommunications Union, MIS 2017 ("Цифровая трансформация", 2018).

Варто підкреслити той факт, що українське законодавство досі не містить визначення ШСД, а отже, невизначеними залишаються і вимоги до мінімальної швидкості для широкосмугового доступу. з 10 найбільших операторів ШСД в Україні мінімальну швидкість на рівні 10 Мбіт/с гарантують тільки два. Чотири оператори вказують у договорах із користувачами мінімальну швидкість доступу у номінальні 64 кбіт/с, ще чотири - не вказують її взагалі ("Потенціал розвитку ринку", 2017).

Перший етап розгортання цифрової нерівності на локальному рівні позначається на кількісних показниках України, що відображені в даних світових рейтингів щодо рівня розвитку інформаційного суспільства. Проведений автором моніторинг індексу мережевої готовності та рівня розвитку IКТ в Україні протягом 2012-2016 pр. (див. рис. 2) засвідчив незначну позитивну динаміку: за цим показником Україна 375 місця у 2012 році піднялась на 10 пунктів у 2016 році, посівши 65-те місце (після 2016 року інформація про дане рейтингування відсутня).

Моніторинг зміни позицій України у рейтингу глобального дослідження за показниками розвитку інновацій також виявив стабільну та впевнену позитивну динаміку: протягом 2014-2018 рр. Україна піднялась із 63 на 43 місце (див. рис. 3). 


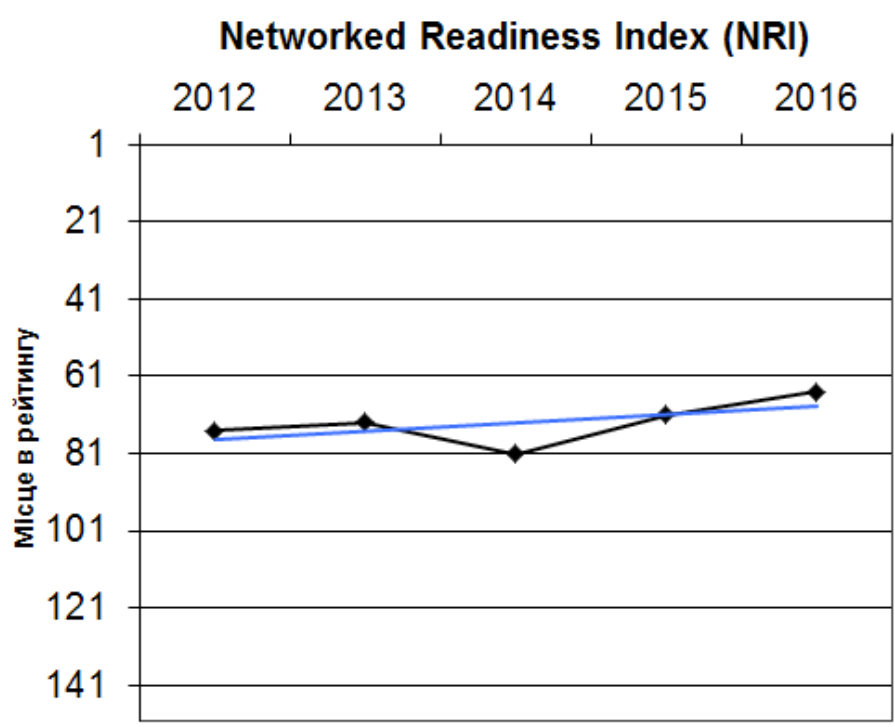

Рисунок 2. Позиції України в світовому рейтингу Networked Readiness Index.

Global innovation index

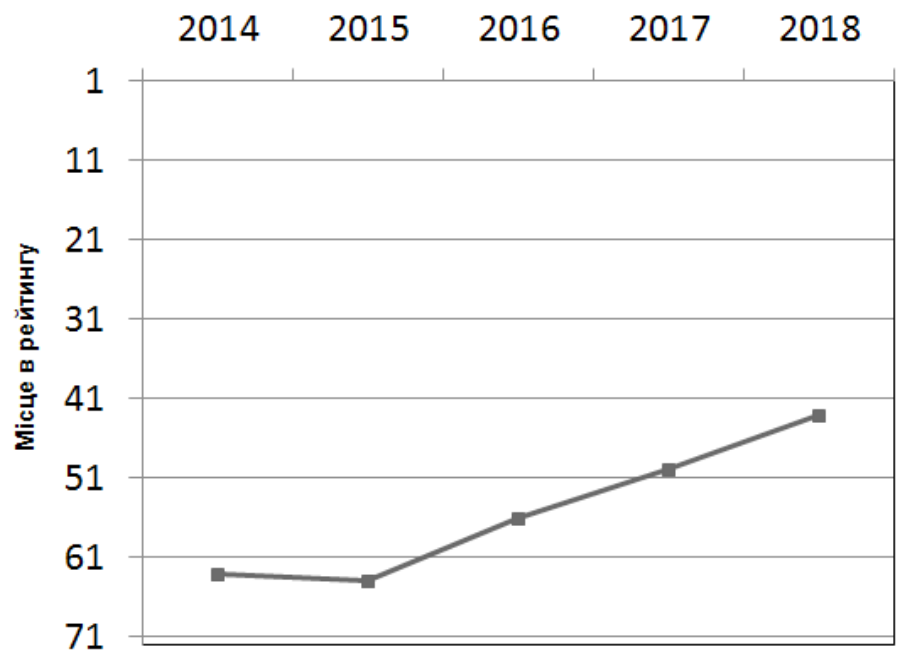

Рисунок 3. Позиції України в світовому рейтингу Global Innovation Index.

Водночас у комплексному показнику, що демонструє готовність та можливості національних державних структур у використанні IKT для надання громадянам послуг, за період із 2010 по 2018 роки Україна показала загальну негативну динаміку, опустившись із 54 на 82 місце у рейтингу (див. рис. 4).

Аналіз позицій України щодо рівня розвитку IКТ за міжнародними індексами дає можливість зробити висновок про те, що наша держава залишається в ролі 
Український журнал з бібліотекознавства та інформаційних наук. Випуск 3 (2019) Ukrainian Journal on Library and Information Science. Issue 3 (2019)

відносно відсталої країни. Враховуючи прямий зв’язок технологічної відсталості держави з її економічними результатами, подолання цифрової нерівності стає однією з необхідних передумов задля виходу України із соціально-економічної кризи. В даному контексті показовою видається статистика Всесвітнього економічного форуму, яка свідчить про те, що кожне додаткове $10 \%$-не збільшення проникнення широкосмугового інтернету може призвести до зростання показника ВВП на душу населення в країнах з перехідною економікою на 1, 2 \% ("The Global Competitiveness Report", 2019).

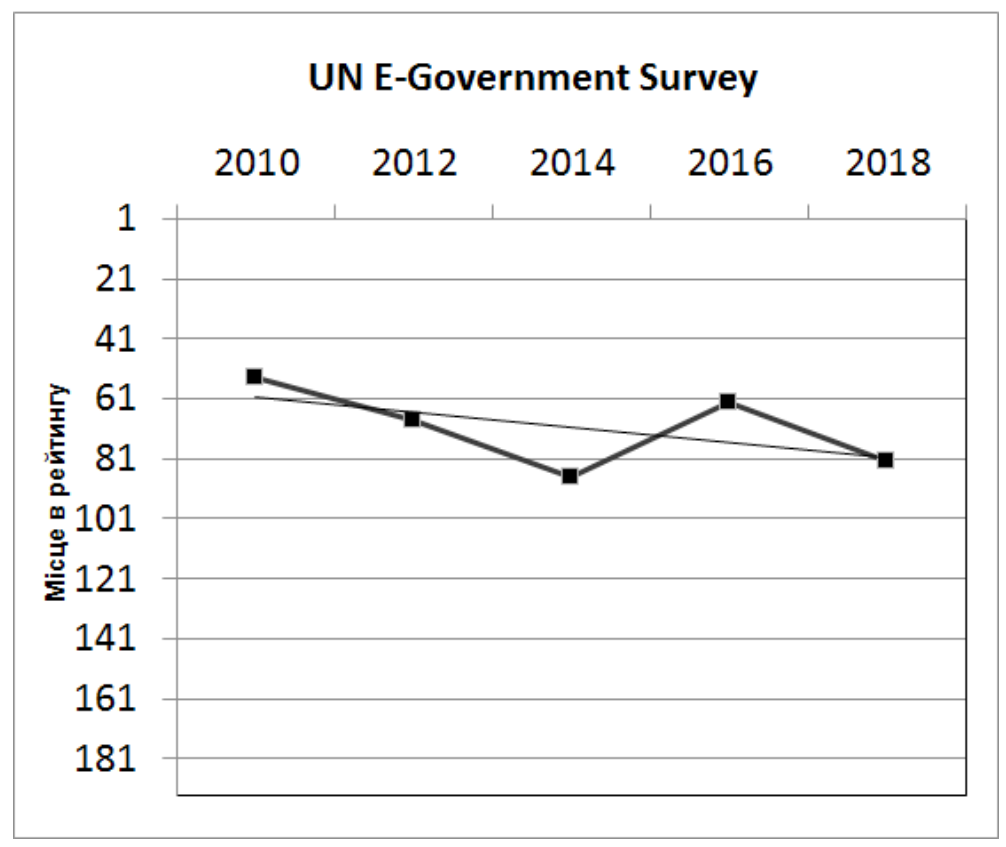

Рисунок 4. Позиції України в світовому рейтингу UN E-Government Survey.

Важливо зазначити, що разом із належним технологічним забезпеченням, необхідною передумовою скорочення цифрової нерівності є усунення дисбалансу в освоєнні цифрового ресурсу, пов'язаного з відсутністю базових навичок користування сучасними IKT та комп'ютерною технікою. Насамперед, мова йде про найбільш вразливі з погляду адаптації до технічних інновацій категорії населення, зокрема, людей старшого та похилого віку. Діти та молодь вільно володіють технічними новинками i, як наслідок, мають можливість безперешкодного доступу до цифрового простору та інформації. Дорослі люди проходять процес технологічної адаптації складніше, тоді як людям похилого віку, адаптаційні можливості яких суттєво зменшуються, зовсім загрожує цифрова маргіналізація.

У своїй широковідомій статті «Аборигени та іммігранти цифрового світу» М. Пренскі, ведучи мову про процес трансформації сучасної освіти, вказує на глибоку та принципово нову проблему розділення старшого та молодшого поколінь на «цифрових аборигенів» та «цифрових іммігрантів». Перші народжені в еру активного використання мережі інтернет і $€$ «носіями мови» - рідної для них мови 
комп’ютерів, відеоігр та інтернету. Другі - говорять архаїчною мовою доцифрової епохи i «вчаться адаптуватися до середовища, як усі звичайні іммігранти - хтось краще, хтось гірше, - але всі вони завжди якоюсь мірою зберігають свій “акцент”, тобто, однією ногою вони завжди залишаються в минулому» (Prensky, 2001).

Таким чином, сучасні «цифрові іммігранти», схильні до ризиків цифрової нерівності, у випадку відсутності у них належної комп’ютерної обізнаності фактично втрачають свою рівноправність як у реальному світі, так і в кіберпросторі. В даному контексті слід зауважити, що частка людей похилого віку в структурі населення зростає високими темпами у розвинутих країнах та багатьох країнах, що розвиваються. Україна входить до тридцятки «найстаріших» країн світу (за даними Міністерства соціальної політики, в Україні близько 12 млн пенсіонерів), тому питання цифрової інклюзії та загальної інформаційної соціалізації даної категорії населення потребує додаткової уваги при формуванні політики вирішення проблеми цифрової нерівності в нашій державі (детальніше про це див.: Миськевич, 2015, 2017).

Комплексний підхід до розуміння явища цифрової нерівності вимагає врахування еволюції цього феномену, а тому, передбачає ретельний аналіз нинішніх тенденцій його розгортання. Зокрема, уваги потребує поява якісно нового етапу розгортання цифрової нерівності, що виникає - як не парадоксально - у міру зменшення цифрового розриву в соціумі та подолання об'єктивних факторів цифрової нерівності, що вказані вище. Справа у тому, що навіть на тому етапі становлення інформаційного суспільства, коли питання оволодіння навичками користування IKT та вільного доступу до цифрового та медіа простору вже не стоїть, а віртуальні комунікації сприймаються як цілком природні, розгортання цифрової нерівності переходить на якісно новий етап. В англомовних наукових ресурсах специфіка такої трансформації характеризується термінами Knowledge divide (знаннєва нерівність) та Second-level digital divide (другий рівень цифрової нерівності), що позначають нерівність у ступені ефективності та якості використання цифрового ресурсу та новітніх IKT.

Другий етап розгортання цифрової нерівності в сучасному суспільстві диференціює споживачів контенту в мережі інтернет та сучасних інформаційних технологій i, власне, їх розробників. Так, нові застосунки дають змогу нині будь-кому, хто знайомий із комп’ютером та підключений до мережі, стати творцем контенту, проте його левова частка, як, наприклад, загальнодоступні блоги, створюється невеликою частиною споживачів. При цьому, в основному, використовуються сервіси на основі технології Web 2.0, такі як Facebook, YouTube, Twitter, які уможливлюють для користувачів створення контенту (шляхом публікацій фотографій, оновлень статусів тощо). Нерозуміння повною мірою принципів функціонування таких сервісів призводить до стану цифрового розриву між тими, у кого $€$ навички та розуміння для комплексного використання технології, і тими, хто є її пасивними споживачами (Reilley, 2011). Тобто, з одного боку, кількість людей, які вміють користуватися різного роду гаджетами та девайсами, зростає, а з іншого - зменшується кількість тих, кого справді можна віднести до «просунутих» користувачів. Із цього приводу голова BT Group (British Telecommunications plc) Г. Патерсон (Gavin Patterson) зазначає, що пасивних користувачів, насправді, мало цікавить, як технологія, від якої вони залежні, функціонує. Такий, за визначенням експерта, 
Український журнал з бібліотекознавства та інформаційних наук. Випуск 3 (2019) Ukrainian Journal on Library and Information Science. Issue 3 (2019)

парадокс технологічної грамотності має серйозні наслідки, позаяк у часи Четвертої Промислової Революції, яку, на його думку, ми зараз спостерігаємо, фундаментальна технічна грамотність стає справді необхідною (Patterson, 2016). В епоху глобальної цифровізації інформаційні технології стають невід’ємною частиною сучасного життя - від записної книжки в телефоні, яка є базою даних, та бортового комп’ютера автомобіля як спеціальної обчислювальної системи - до Big Data, технології блокчейн та розробок у сфері штучного інтелекту. Цифрові технології постійно модифікуються та ускладнюються, стаючи все менш зрозумілими для обивателя. Технологічний прогрес загалом розвивається настільки швидкими темпами, що спеціалісти технологічної індустрії, які займаються впровадженням, підтримкою та розробками кібернетичних надбань починають формувати в наш час «технологічний вищий клас».

Принагідно варто зауважити, що в самій технологічній еліті також відбувається «розшарування», оскільки на лідируючі позиції виходять ті, хто не просто створює технологію, а й пропонує за допомогою цієї технології комунікацію. Так, згідно 3 даними рейтингу 15-ти найуспішніших світових брендів від агенції Interbrand, y 2018 р. на перші місця стрімко вийшли Google (із 14-ї позиції станом на 2008 р. на 2-гу у 2018 р.) та Aмazon (iз 15-ї позиції станом на 2014 р. на 3-тю у 2018 р.), посунувши в рейтингу IBM та Microsoft ("Top 15 Best Global Brands", 2019).

Зміщення фокусу дослідження другого етапу розгортання цифрової нерівності в геополітичну площину дає змогу простежити специфіку її проявів в умовах глобальної конкуренції у сфері новітніх інформаційних технологій. Моніторинг світового ринку ІКТ-послуг показав, що станом на 2018 р. основними його експортерами $є$ Ірландія, Індія та США - їх частка становить $1 / 4$ від усього світового експорту інформаційних та телекомунікаційних послуг ("Мировой рынок", 2018). Україна впевнено демонструє позитивну динаміку експорту послуг у сфері IKT, значну частку яких становлять послуги з апаратно-програмного забезпечення, послуги з обробки даних, телекомунікаційні послуги (забезпечення доступу до мобільного зв'язку та інтернету) й інформаційні послуги. Маючи потужну технологічну експертизу, українські IT-компанії надають своїм іноземним клієнтам і ряд консалтингових послуг. У період із 2007 по 2016 рік показник України в експорті ІКТ-послуг збільшився на 1944, 9 млн дол., а темп приросту становить аж 84,2 \% (Нікітіна, 2017).

Проте наша держава все ж продовжує залишатися країною наздоганяючої інформатизації, тоді як головними гравцями ринку технологій глобального значення стають ті держави, які просувають інноваційний розвиток сфери «віртуального виробництва», зокрема, технологій на базі штучного інтелекту, та володіють не тільки сервісною складовою інформаційної індустрії, а й виробляють ії продукцію - сучасні засоби інформатизації та медіатизації. До слова, у 2018 р. до п’ятірки країн-лідерів експорту IKT-продукції увійшли Китай, Південна Корея, Тайвань, Сінгапур та Німеччина ("Максимум ИКТ-товаров", 2019).

На другому етапі розгортання цифрової нерівності особлива небезпека криється у монополізації розробок в інформаційній сфері. По-перше, сьогодні можливості легального «просунутого користування» сучасними IT-технологіями чітко обумовлюються їх виробниками: наприклад, розробники апаратного забезпечення передбачають можливість роботи своїх систем тільки за умови використання 
певного програмного забезпечення, а наявні ліцензійні операційні системи, своєю чергою, не дають змоги відмовитися від непотрібних застосунків без порушення ліцензійної угоди та налаштувати операційну систему під себе (вибирати можна лише інтерфейс). Все це призводить до все більшого споживання інформаційних товарів і послуг, власниками та постачальниками яких є все ті ж країни-лідери. Стає очевидним, що в інформаційній сфері виникають монополістичні тенденції, а сама можливість технологічного прориву в країнах із «наздоганяючою» інформатизацією потрапляє під питання (Кислова, 2017, с. 252).

Об’єктивні ризики цифрової нерівності на рівні країн криються також у неухильному процесі цифровізації майже усіх систем життєзабезпечення сучасного суспільства. Так, зокрема, в Україні, інформатизація держсектору, паливно-енергетичного комплексу, військово-промислового і телекомунікаційного комплексів, економіки та фінансів тощо відбувається з використанням зарубіжних цифрових платформ, українські аналоги яких відсутні. Відтак, створюються бази стратегічно важливих для держави даних, що зберігаються на іноземному обладнанні з іноземним програмним забезпеченням, що ставить під сумнів питання конфіденційності та безпеки їх функціонування. Те саме стосується і доступу до даних, що зберігаються на хмарних серверах.

Підсумовуючи, слід зазначити, що загальносвітовими тенденціями в проявах проблеми цифрової нерівності залишається її актуальність на глобальному, регіональному та локальному рівнях, географічний та соціальний чинники (Північ Південь, мегаполіси - села), а також початок другого етапу розгортання цифрової нерівності - розриву між тими, хто встановлює правила цифрової спільноти та тими, хто за цими правилами змушений жити.

Особливістю ситуації в Україні є одночасне розгортання обох етапів цифрової нерівності, що провокує негативний синергетичний ефект посилення проблеми. Незважаючи на складність ситуації, останні роки засвідчили позитивні зрушення в питаннях скорочення цифрового розриву всередині країни, утім проблема цифрової нерівності між містами та селами, а також за віковою ознакою все ще залишається актуальною. Окрім того, доволі гостро постає питання залежності України від імпорту ІКТ-продукції, що створює об'єктивні ризики для ï̈ безпеки. Тому, сьогодні вкрай важливим є здійснення державної політики у напрямку мінімізації деструктивних проявів цифрової нерівності, що передбачатиме:

- подолання інфраструктурних обмежень та забезпечення якісного процесу інформатизації;

- підвищення технологічної обізнаності якнайширшого кола громадян, а також плекання та підтримку власних висококваліфікованих IT-спеціалістів, які не обмежуватимуться вторинною роллю підрядників та надавачів послуг у сфері IKT, а й будуть здатними виходити на сучасний ринок із власними цифровими концептами та продуктами;

- стимулювання та розвиток науково-дослідних центрів і створення нових підприємств IT-сфери, що дозволятимуть у подальшому здійснювати імпортозаміщення стратегічно важливих технологій задля забезпечення цифрового суверенітету та інформаційної безпеки в нашій державі. 
Український журнал з бібліотекознавства та інформаційних наук. Випуск 3 (2019)

Ukrainian Journal on Library and Information Science. Issue 3 (2019)

\section{СПИСОК ПОСИЛАНЬ}

Аніщенко О. В. Інформаційна нерівність у сучасному суспільстві. Інформаційно-комунікаційні технологї̈ в сучасній освіті: досвід, проблеми, перспективи: зб. матеріалів III Міжнар. наук.-практ. конф. Київ ; Львів, 2012. Вип. 3, ч. 1. С. 100-103.

Афанасьева А. С. Цифровое неравенство как проблема внедрения электронного правительства в России. Общество: политика, экономика, право. 2015. № 6. С. 16-17. URL: http://dom-hors.ru/rus/files/arhiv_zhurnala/pep/2015-6/politics/afanasyeva.pdf （дата обращения: 15.05.2019).

Бакіров В. Соціальна нерівність: нові виклики. Тези доповідей та виступів учасників III Конгресу Соціологічної асоціації України «Нові нерівності - нові конфлікти: шляхи подолання» (Харків, 12-13 жовт. 2017 р.). Харків, 2017. C. 5-7. URL: http://www.sau.kiev.ua/ docs/20171205/tezi.pdf (дата звернення: 15.05.2019).

Вартанова Е. Интернет для каждого: реальность или утопия? Информационное общество. 2000. Вып. 1. С. 40-43. URL: http://emag.iis.ru/arc/infosoc/emag.nsf/BPA/9a3caabea61c3 e09c32569ad00447d4a (дата обращения: 15.05.2019).

Володенков С. В. Роль информационно-коммуникационных технологий в современной политике. Научный ежегодник Института философии и права Уральского отделения Российской академии наук, 2018. Т. 18, вып. 2. С. 69-86. doi: 10.17506/ryipl.2016.18.2.6986.

Вороненкова Г. Цифровое неравенство в парадигме научных дискуссий в Германии. Mедиаскоп. 2016. Вып. 4. URL: http://www.mediascope.ru/2200 (дата обращения: 15.05.2019).

Гайнанов Д., Шарифьянов Т. Эволюция цифрового неравенства и инструментарий нейтрализации его последствий. Региональная экономика: теория и практика. 2014. Вып. 22. URL: https://cyberleninka.ru/article/n/evolyutsiya-tsifrovogo-neravenstva-iinstrumentariy-neytralizatsii-ego-posledstviy (дата обращения: 15.05.2019).

Городенко Л. М. Цифрова та інформаційна нерівність у мережевій комунікації. Інформаційне суспільство. 2012. Вип 16. С. 56-59.

Дедюлина М. Цифровое неравенство: философское осмысление. Studia Humanitatis 2017. № 2. URL: http://st-hum.ru/en/node/537 (дата обращения: 15.05.2019).

Дятлов С. А., Лобанов О. С. Конвергенция информационных пространств как фактор снижения цифрового неравенства в Евразийском экономическом союзе. Региональная экономика и управление. 2017. № 2 (50). URL: https://eee-region.ru/article/5003/ (дата обращения: 15.05.2019).

Єршова О. Л. Чинники подолання «цифрової нерівності»: світовий досвід та можливості для України. Економіко-математичне моделювання соціально-економічних систем. 2016. Вип. 21. С. 106-115.

Емелин В. Технологии как фактор трансформации идентичности: становление HomoTechnologicus. Национальный психологический журнал. 2016. Т. 21, №1. С. 9-18.

Зубок Ю. А., Чупров В. И. Угрозы в трансформирующейся среде обитания как фактор социальных рисков: прогнозирование и регулирование. Социологические исследования. 2017. № 5. С. 57-67.

Каратеев А. Ю. Демократия и цифровое неравенство. Русская политология. 2018. № 4 (9). URL: https://cyberleninka.ru/article/n/demokratiya-i-tsifrovoe-neravenstvo (дата обращения: 10.05.2019).

Карелов С. Анализ влияния технологий ИИ на геополитику. 2018. URL: https://u.to/jK96FA (дата обращения: 10.05.2019).

Кислова О. М. «Великі дані» як чинник інформаційної нерівності. Тези доповідей та виступів учасників ІІІ Конгресу Соціологічної асоціації України «Нові нерівності - нові конфлікти: шляхи подолання» (Харків, 12-13 жовт. 2017 р). URL: http:/www.sau.kiev.ua/ docs/20171205/tezi.pdf (дата звернення: 15.05.2019). 
Кузнецова А. Природа технологизации. Международный журнал экспериментального образования. 2016. № 9, ч. 1. С. 145.

Кутырев В. Культура и технология: борьба миров. Берлин ; Москва: Directmedia, 2015. 247 с. Максимум ИКТ-товаров продает Китай, а покупают страны СНГ. Экономическая газета. 2019. URL: https://neg.by/novosti/otkrytj/maksimum-ikt-tovarov-prodaet-kitaj (дата обращения: 18.05.2019).

Мацегора К. У країні стартує цифрова трансформація економіки. Урядовий кур`єр. 2018. 18 січ. C. 2. URL: https://ukurier.gov.ua/uk/articles/u-krayini-startuye-cifrovatransformaciya-ekonomik/ (дата звернення: 15.05.2019).

Мировой рынок информационных и телекоммуникационных услуг. 2018. Институт анализа инвестиционной политики. URL: http://xn--80aplem.xn--p1ai/analytics/Mirovoj-rynok-informacionnyh-i-telekommunikacionnyh-uslug/ (дата обращения: 18.05.2019).

Миськевич Т. Бібліотеки в системі безперервної освіти: реалізація завдань інформаційної соціалізації через неформальну освіту. Наукові праці Національної бібліотеки України імені В. І. Вернадського. Київ, 2017. Вип. 48. С. 515-524.

Миськевич Т. Роль і можливості вітчизняних бібліотек у процесах інформаційної соціалізації. Наукові праці Національної бібліотеки України імені В. І. Вернадського. Київ, 2015. Вип. 41. С. 154-165.

Михальчук С. О. «Цифровий розрив» як деструктивний фактор розвитку електронної демократії.Панорама політологічних студій. 2014. Вип. 12. С. 39-45.

Нікітіна I. М. Аналіз ринку послуг в сфері IKT. 2017. URL: http://ela.kpi.ua/bitstream/1234567 89/23887/1/S.78-83.pdf (дата звернення: 18.05.2019).

Питання розвитку цифрової культури українського соціуму. Національний інститут стратегічних досліджень. 2019. URL: http://www.euroosvita.net/prog/print.php/prog/print. php?id=3521\&- (дата звернення: 18.05.2019).

Потенціал розвитку ринку широкосмугового доступу в Україні становить 23 млрд грн, BRDO. Урядовий портал. 2017. URL: http://old.kmu.gov.ua/kmu/control/ru/publish/ printable_article?art_id=250070077 (дата звернення: 14.05.2019).

Ржевська Н. Ф. Стратегічні прогнози щодо подолання інформаційної нерівності в умовах глобалізації. Науковий вісник Інституту міжнародних відносин Національного авіаційного університету. Серія: Економіка, право, політологія, туризм. 2010. Вип. 2. C. $104-110$.

Родионова В. Новые методологические возможности понятий «социальные практики» и «технологизация» в контурах социальной философии и социологии. Гуманитарий Юга России. 2017. Т. 23, №. 1. С. 191-195.

Удовик В. Е. Роль информационно-коммуникационных технологий в современном обществе. 2010. URL: http://www.mospolytech.ru/science/mami145/scientific/article/s12/ s12_36.pdf(дата обращения: 18.05.2019).

Цифровая трансформация. Стратегия, инфраструктура, реализация. ITU Workshop. 2018. URL: https://u.to/EzVVFQ (дата обращения: 16.05.2019).

Цифровое неравенство. Почему отсутствие интернета влияет на качество жизни и как это преодолеть в Украине. 2019. URL: https://gagadget.com/37699-tsifrovoe-neravenstvo-pochemu-otsutstvie-interneta-vliyaet-na-kachestvo-zhizni-i-kak-eto-preodolet/ (дата обращения: 17.05.2019).

Цілі Сталого Розвитку: Україна. Національна доповідь. 2017. URL: http:/un.org.ua/images/ SDGs_NationalReportUA_Web_1.pdf (дата звернення: 16.05.2019).

Чарковський Я. Є. Технологізація суспільних сфер життєдіяльності людини. Наукові записки Вінницького державного педагогічного університету імені Михайла Коцюбинського. Серія: Педагогіка і психологія. 2016. Вип. 47. С. 22-26.

Чмерук Г., Краліч В. (2018) Цифрова нерівність в Україні: аналіз та шляхи подолання. Молодий вчений. 2018. № 7 (1). С. 289-293. 
Український журнал з бібліотекознавства та інформаційних наук. Випуск 3 (2019) Ukrainian Journal on Library and Information Science. Issue 3 (2019)

Шабашев В., Щербакова Л. Тенденции цифрового равенства/неравенства в современном мире. Социологические исследования. 2016. № 9. С. 3-12.

Beck U. Risk Society, Towards a New Modernity / Trans. from the German by M. Ritter, and with an Introduction by S. Lash and B. Wynne. London: Sage Publications, 1992 [originally publ. 1986]. 260 pp.

Capurro R. Why Information Ethics? International Journal of Applied Research on Information Technology and Computing Year. 2018. Vol. 9, Issue 1. P. 50-52. doi: 10.5958/09758089.2018.00005.2.

Chesser A., Burke A., Reyes J., Rohrberg T. Navigating the digital divide: A systematic review of eHealth literacy in underserved populations in the United States. Informatics for Health and Social Care. 2016. Vol. 41, Issue 1. P.1-19. doi: 10.3109/17538157.2014.948171.

Cruz-Jesus F., Oliveira T., Bacao F. The Global Digital Divide: Evidence and Drivers. Journal of Global Information Management (JGIM). 2018. Vol. 26, Issue 2. P. 1-26. doi: 10.4018/ JGIM.2018040101.

Dobransky K., Hargittai E. Unrealized Potential: Exploring the Digital Disability Divide. Poetics.2016. Vol. 58. P. 18-28. doi:10.1016/j.poetic.2016.08.003.

Elliott T., Earl J. Online protest participation and the digital divide: Modeling the effect of the digital divide on online petition-signing. New Media \& Society. 2016. Vol. 20, Issue: 2. P. 698-719. doi: 10.1177/1461444816669159.

Fox G., Connolly R. Mobile health technology adoption across generations: Narrowing the digital divide. Information Systems Journal. 2018. January. doi: 10.1111/isj.12179.

Global Digital Divide. 2019. URL: http://old.driven-by-data.net/about/global-digital-divide/\#/0 (accessed: 17.05.2019).

Goggin G. Disability and digital inequalities: Rethinking digital divides with disability theory. Theorizing digital dividesthe Internet and social ineguality in international perspective / Eds. M. Ragnedda, G. W. Muschert. New York, NY: Routledge Publishing, 2017.

Griffy-Brown C., Earp B. D., Rosas O. Technology and the good society. Technology in Society, inpress. 2018. URL: https://www.academia.edu/35504250/Technology_and_the_good_society (accessed: 17.05.2019).

Hilbert M. The bad news is that the digital access divide is here to stay: Domestically installed bandwidths among 172 countries for 1986-2014. Telecommunications Policy. 2016. Vol 40, P. 567-581.

Hong Y. A., Zhou Z. A Profile of eHealth Behaviors in China: Results From a National Survey Show a Low of Usage and Significant Digital Divide. Front. Public Health. 2018. Issue 6. P. 274. doi: 10.3389/fpubh.2018.00274.

Hongladarom S. Information Divide, Information Flow and Global Justice. International Review of Information Ethics. 2007. Vol. 7. URL: http://www.i-r-i-e.net/inhalt/007/08-hongladarom. pdf (accessed: 17.05.2019).

Jamrisko M., Saraiva C. These Are the World's Most Miserable Economies. Bloomberg. 2018. URL: https://www.bloomberg.com/news/articles/2018-02-14/most-miserable-economies-of-2018-stay-haunted-by-inflation-beast (accessed: 15.05.2019).

Kenneth E. H. Legal, Social, and Ethical Issues of the Internet. 2004. URL: https:/www.oreilly. com/library/view/handbook-of-information/9780471648314/28_chapter-17.html (accessed: 17.05.2019).

Latulippe K., Hamel C., Giroux D. Social Health Inequalities and eHealth: a Literature Review With Qualitative Synthesis of Theoretical and Empirical Studies. Journal of Medical Internet Research. 2017. Vol. 19, No. 4. P. 136. doi: 10.2196/jmir.6731.

Patterson G. The Tech Literacy Imperative. Project Syndicate. 2016. 18.01. URL: https://www. project-syndicate.org/commentary/tech-literacy-for-digital-natives-by-gavin-patterson-2016-01/russian?barrier=accesspaylog (дата обращения: 10.05.2019). 
Prensky M. Digital Natives Digital Immigrants. MCB University Press. 2001. Vol. 9. № 5. URL: https://www.marcprensky.com/writing/Prensky\%20-\%20Digital\%20Natives,\%20 Digital\%20Immigrants\%20-\%20Part1.pdf (accessed: 17.05.2019).

Ragnedda M., Muschert G. Theorizing Digital Divides. Routledge Advances in Sociology. Abingdon : Taylor \& Francis, 2017.

Reilly C. A. Teaching Wikipedia as a Mirrored Technology. First Monday. 2011. Vol. 16, No. 1. URL: https://ojphi.org/ojs/index.php/fm/article/view/2824/2746 (accessed: 17.05.2019).

The Global Competitiveness Report 2014-2015. The World Economic Forum. 2019. URL: http:// reports.weforum.org/global-competitiveness-report-2014-2015/ (accessed: 12.05.2019).

Top 15 Best Global Brands Ranking (2000-2018). 2019. URL: https://www.youtube.com/ watch?v=BQovQUga0VE (accessed: 18.05.2019).

Vartanova E., Smirnova O. Digital Divide as a Problem of Information Society. World of Media: Year book of Russian Media and Journalism Studies. 2009. P. 5-20.

Yun Ch. The Technologization of Politics: The Internet and the Electronic Citizen. Undergraduate Awards. 2015. № 2. URL: https://ir.lib.uwo.ca/ungradawards_2015/2 (accessed: 15.05.2019).

Zacher L. W. Technologization of Man and Marketization of His Activities and Culture of the Future. Technology, Society and Sustainability / Ed. L. W. Zacher. Springer, Cham. 2017. P. 27-48.

\section{REFERENCES}

Anishchenko, O.V. (2012). Informatsiina nerivnist u suchasnomu suspilstvi [Information inequality in modern society]. In Informatsiino-komunikatsiini tekhnolohii v suchasnii osviti: dosvid, problemy, perspektyvy [Information and communication technologies in modern education: experience, problems, prospects], Proceedings of the 3rd Internetional Conference (Vol. 3, issue 1, pp. 100-103). Kyiv; Lviv [in Ukrainian].

Afanasyeva, A.S. (2015). Tcifrovoe neravenstvo kak problema vnedreniia elektronnogo pravitelstva v Rossii [Digital inequality as a problem of the introduction of e-government in Russia]. Obshchestvo: politika, ekonomika, pravo, 6, 16-17. Retrieved from http://dom-hors.ru/rus/ files/arhiv_zhurnala/pep/2015-6/politics/afanasyeva.pdf [in Russian].

Bakirov, V. (2017). Sotsialna nerivnist: novi vyklyky [Social Inequality: the new challenges] Tezy dopovidei ta vystupiv uchasnykiv III Konhresu Sotsiolohichnoi asotsiatsii Ukrainy "Novi nerivnosti - novi konflikty: shliakhy podolannia" [Abstracts of speeches and speeches of the 3rd Congress of the Sociological Association of Ukraine "New inequalities - new conflicts: ways to overcome"] (pp. 5-7). Kharkiv. Retrieved from http://www.sau.kiev.ua/ docs/20171205/tezi.pdf [in Ukrainian].

Vartanova, E. (2000). Internet dlia kazhdogo: realnost ili utopiia? [Internet for everyone: reality or utopia?]. Informatcionnoe obshchestvo, 1, 40-43. Retrieved from http://emag.iis.ru/arc/ infosoc/emag.nsf/BPA/9a3caabea61c3e09c32569ad00447d4a [in Russian].

Volodenkov, S.V. (2018). Rol informatcionno-kommunikatcionnykh tekhnologii v sovremennoi politike [The role of information and communication technologies in modern politics]. Nauchnyi ezhegodnik Instituta filosofii i prava Uralskogo otdeleniia Rossiiskoi akademii nauk, 18, 2, 69-86. doi: 10.17506/ryipl.2016.18.2.6986 [in Russian].

Voronenkova, G. (2016). Tcifrovoe neravenstvo v paradigme nauchnykh diskussii v Germanii [Digital inequality in the paradigm of scientific discussions in Germany]. Mediaskop, 4. Retrieved from http://www.mediascope.ru/2200 [in Russian].

Gainanov, D., \& Sharifianov, T. (2014). Evoliutciia tcifrovogo neravenstva i instrumentarii neitralizatcii ego posledstvii [Evolution of digital inequality and tools to neutralize its consequences]. Regionalnaia ekonomika: teoriia i praktika, 22. Retrieved from https:// 
cyberleninka.ru/article/n/evolyutsiya-tsifrovogo-neravenstva-i-instrumentariyneytralizatsii-ego-posledstviy [in Russian].

Horodenko, L.M. (2012). Tsyfrova ta informatsiina nerivnist u merezhevii komunikatsii [Digital and informational inequality in network communication. Information Society]. Informatsiine suspilstvo, 16, 56-59 [in Ukrainian].

Dediulina, M. (2017). Tcifrovoe neravenstvo: filosofskoe osmyslenie [Digital Inequality: Philosophical Comprehension]. Studia Humanitatis, 2. Retrieved from http://st-hum.ru/en/ node/537 [in Russian].

Diatlov, S.A., \& Lobanov, O.S. (2017). Konvergentciia informatcionnykh prostranstv kak faktor snizheniia tcifrovogo neravenstva v Evraziiskom ekonomicheskom soiuze [Convergence of information spaces as a factor in reducing digital inequality in the Eurasian Economic Union]. Regionalnaia ekonomika i upravlenie, 2 (50). Retrieved from https://eee-region.ru/ article/5003/ [in Russian].

Yershova, O.L. (2016). Chynnyky podolannia «tsyfrovoi nerivnosti»: svitovyi dosvid ta mozhlyvosti dlia Ukrainy [Factors of overcoming «digital inequality»: world experience and opportunities for Ukraine]. Ekonomiko-matematychne modeliuvannia sotsialno-ekonomichnykh system, 21, 106-115 [in Ukrainian].

Emelin, V. (2016). Tekhnologii kak faktor transformatcii identichnosti: stanovlenie Homo Technologicus [Technologies as a factor of identity transformation: the formation of Homo Technologicus]. Natcionalnyi psikhologicheskii zhurnal, 21, 1, 9-18 [in Russian].

Zubok, Iu.A., Chuprov, V.I. (2017). Ugrozy v transformiruiushcheisia srede obitaniia kak faktor sotcialnykh riskov: prognozirovanie i regulirovanie [Threats in a transforming habitat as a social risk factor: forecasting and regulation]. Sotciologicheskie issledovaniia, 5, 57-67 [in Russian].

Karateev, A.Iu. (2018). Demokratiia i tcifrovoe neravenstvo [Democracy and Digital Inequality]. Russkaia politologiia, 4(9). Retrieved from https://cyberleninka.ru/article/n/demokratiya-i-tsifrovoe-neravenstvo [in Russian].

Karelov, C. (2018). Analiz vliianiia tekhnologii II na geopolitiku [Analysis of the impact of AI technology on geopolitics]. Retrieved from https://u.to/jK96FA [in Russian].

Kyslova, O. M. (2017). "Velyki dani" yak chynnyk informatsiinoi nerivnosti [Big data as a factor of informational inequality]. Tezy dopovidei ta vystupiv uchasnykiv III Konhresu Sotsiolohichnoi asotsiatsii Ukrainy "Novi nerivnosti - novi konflikty: shliakhy podolannia" [Abstracts of speeches and speeches of the 3rd Congress of the Sociological Association of Ukraine «New inequalities - new conflicts: ways to overcome»] (pp. 252-253). Kharkiv. Retrieved from http://www.sau.kiev.ua/docs/20171205/tezi.pdf [in Ukrainian].

Kuznetcova, A. (2016). Priroda tekhnologizatcii [The nature of technologization]. Mezhdunarodnyi zhurnal eksperimentalnogo obrazovaniia. 2016, 9, 1,145 [in Russian].

Kutyrev, V. (2015) Kultura i tekhnologiia: borba mirov [Culture and Technology: war of the worlds]. Berlin; Moscow: Directmedia[in Russian].

Maksimum IKT-tovarov prodaet Kitai, a pokupaiut strany SNG [The maximum ICT goods are sold by China, and the CIS countries are buying]. (2019). Ekonomicheskaia gazeta. Retrieved from https://neg.by/novosti/otkrytj/maksimum-ikt-tovarov-prodaet-kitaj [in Russian].

Matsehora, K. (2018, January 18). U kraini startuie tsyfrova transformatsiia ekonomiky [The country is launching a digital transformation of the economy]. Uriadovyi kur'ier, p. 2. Retrieved from https://ukurier.gov.ua/uk/articles/u-krayini-startuye-cifrovatransformaciya-ekonomik/ [in Ukrainian].

Mirovoi rynok informatcionnykh i telekommunikatcionnykh uslug [World market of information and telecommunication services]. (2018). URL: http://xn--80aplem.xn--p1ai/analytics/ Mirovoj-rynok-informacionnyh-i-telekommunikacionnyh-uslug/ [in Russian].

Myskevych, T. (2017). Biblioteky v systemi bezperervnoi osvity: realizatsiia zavdan informatsiinoi sotsializatsii cherez neformalnu osvitu [Libraries in the System of Lifelong Learning: 
Implementation of the Tasks of Information Socialization through Non-Formal Education]. Naukovi pratsi Natsionalnoi biblioteky Ukrainy im. V. I. Vernadskoho, 48, 515-524 [in Ukrainian].

Myskevych, T. (2015). Rol i mozhlyvosti vitchyznianykh bibliotek u protsesakh informatsiinoi sotsializatsii [The role and capabilities of domestic libraries in the processes of information socialization]. Naukovi pratsi Natsionalnoi biblioteky Ukrainy im. V. I. Vernadskoho, 41, 154-165 [in Ukrainian].

Mykhalchuk, S.O. (2014). "Tsyfrovyi rozryv" yak destruktyvnyi faktor rozvytku elektronnoi demokratii ["Digital divide" as a destructive factor in the development of e-democracy]. Panorama politolohichnykh studii, 12, 39-45 [in Ukrainian].

Nikitina, I.M. (2017). Analiz rynku posluh v sferi ICT [Analysis of the market of services in the field of ICT]. Retrieved from http://ela.kpi.ua/bitstream/123456789/23887/1/S.78-83.pdf [in Ukrainian].

Pytannia rozvytku tsyfrovoi kultury ukrainskoho sotsiumu [Issues of development of digital culture of Ukrainian society]. (2019). Natsionalnyi instytut stratehichnykh doslidzhen. Retrieved from http://www.euroosvita.net/prog/ print.php/prog/print.php?id=3521\&[in Ukrainian].

Potentsial rozvytku rynku shyrokosmuhovoho dostupu v Ukraini stanovyt 23 mlrd hrn, - BRDO [The potential of the broadband market development in Ukraine is 23 billion USD, BRDO]. Government portal. Retrieved from http://old.kmu.gov.ua/kmu/control/ru/publish/printable_article?art_id=250070077 [in Ukrainian].

Rzhevska, N. (2010) Stratehichni prohnozy shchodo podolannia informatsiinoi nerivnosti $\mathrm{v}$ umovakh hlobalizatsii [Strategic forecasts for overcoming information inequality in the context of globalization]. Naukovyi visnyk Instytutu mizhnarodnykh vidnosyn Natsionalnoho aviatsiinoho universytetu. Seriia: Ekonomika, pravo, politolohiia, turyzm, 2, 104-110 [in Ukrainian].

Rodionova, V. (2017). Novye metodologicheskie vozmozhnosti poniatii «sotcialnye praktiki» $\mathrm{i}$ «tekhnologizatciia» v konturakh sotcialnoi filosofii i sotciologii [New methodological possibilities of the concepts of «social practices» and «technologicalization» in the contours of social philosophy and sociology]. Gumanitarii Iuga Rossii, 23, 1, 191-195 [in Russian].

Udovik, V.E. (2010). Rol informatcionno-kommunikatcionnykh tekhnologii v sovremennom obshchestve [The role of information and communication technologies in modern society]. Retrieved from http://www.mospolytech.ru/science/mami145/scientific/article/s12/ s12_36.pdf [in Russian].

Tcifrovaia transformatciia. Strategiia, infrastruktura, realizatciia [Digital Transformation. Strategy, infrastructure, implementation]. (2018). ITU Workshop. Retrieved from https:/u.to/ EzVVFQ [in Russian].

Tcifrovoe neravenstvo. Pochemu otsutstvie interneta vliiaet na kachestvo zhizni i kak eto preodolet v Ukraine [Digital Inequality. Why the absence of the Internet affects the quality of life and how to overcome it in Ukraine]. (2019). Retrieved from https://gagadget. com/37699-tsifrovoe-neravenstvo-pochemu-otsutstvie-interneta-vliyaet-na-kachestvo-zhizni-i-kak-eto-preodolet/ [in Russian].

Tsili Staloho Rozvytku:Ukraina [Sustainable Development Goals: Ukraine]. (2017). Natsionalna dopovid. Retrieved from http://un.org.ua/images/SDGs_NationalReportUA_Web_1.pdf [in Ukrainian].

Charkovskyi, Ya.Ye. (2016). Tekhnolohizatsiia suspilnykh sfer zhyttiediialnosti liudyny [Technology of the social spheres of human life]. Naukovi zapysky Vinnytskoho derzhavnoho pedahohichnoho universytetu imeni Mykhaila Kotsiubynskoho. Seriia: Pedahohika i psykholohiia chology, 47, 22-26 [in Ukrainian]. 
Український журнал з бібліотекознавства та інформаційних наук. Випуск 3 (2019) Ukrainian Journal on Library and Information Science. Issue 3 (2019)

Chmeruk, H., \& Kralich, V. (2018). Tsyfrova nerivnist v Ukraini: analiz ta shliakhy podolannia [Digital inequality in Ukraine: analysis and ways to overcome]. Molodyi vchenyi, 7 (1), 289-293 [in Ukrainian].

Shabashev, V., \& Shcherbakova, L. (2016). Tendentcii tcifrovogo ravenstva / neravenstva v sovremennom mire [Digital Equality / Inequality Trends in the Modern World]. Sotciologicheskie issledovaniia, 9, 3-12 [in Russian].

Beck, U. (1992). Risk Society, Towards a New Modernity. (M. Ritter, Trans.). London: Sage Publications, 1992 [in English].

Capurro, R.(2018). Why Information Ethics? International Journal of Applied Research on Information Technology and Computing Year, 9, 1, 50-52. doi: 10.5958/0975-8089.2018.00005.2 [in English].

Chesser, A., Burke, A., Reyes, J., \& Rohrberg T. (2016). Navigating the digital divide: A systematic review of eHealth literacy in underserved populations in the United States. Informatics for Health and Social Care, 41, 1, 1-19. doi: 10.3109/17538157.2014.948171 [in English].

Cruz-Jesus, F., Oliveira, T., \& Bacao, F. (2018). The Global Digital Divide: Evidence and Drivers. Journal of Global Information Management (JGIM), 26, 2, 1-26. doi: 10.4018/ JGIM.2018040101 [in English].

Dobransky, K., \& Hargittai, E. (2016). Unrealized Potential: Exploring the Digital Disability Divide. Poetics, 58, 18-28. doi: 10.1016/j.poetic.2016.08.003 [in English].

Elliott, T., \& Earl, J. (2016). Online protest participation and the digital divide: Modeling the effect of the digital divide on online petition-signing. New Media \& Society, 20, 2, 698-719. doi: 10.1177/1461444816669159 [in English].

Fox, G., \& Connolly, R. (2018). Mobile health technology adoption across generations: Narrowing the digital divide. Information Systems Journal. January. doi: 10.1111/isj.12179 [in English].

Global Digital Divide. (2019). Retrieved from http://old.driven-by-data.net/about/global-digital-divide/\#/0 [in English].

Goggin, G. (2017). Disability and digital inequalities: Rethinking digital divides with disability theory. In M. Ragnedda \& G. Muschert (Eds.), Theorizing digital divides the Internet and social ineguality in international perspective. New York, NY: Routledge Publishing [in English].

Griffy-Brown, C., Earp, B.D., \& Rosas, O. (2018). Technology and the good society. Technology in Society, in press. Retrieved from https://www.academia.edu/35504250/Technology_ and the_good_society [in English].

Hilbert, M. (2016). The bad news is that the digital access divide is here to stay: Domestically installed bandwidths among 172 countries for 1986-201. Telecommunications Policy, 40 (6), 567-581 [in English].

Hong Y.A, \& Zhou, Z. (2018). A Profile of eHealth Behaviors in China: Results From a National Survey Show a Low of Usage and Significant Digital Divide. Front. Public Health, 6:274. doi: 10.3389/fpubh.2018.00274 [in English].

Hongladarom, S. (2007).I nformation Divide, Information Flow and Global Justice International Review of Information Ethics, 7. Retrieved from http://www.i-r-i-e.net/inhalt/007/08hongladarom.pdf [in English].

Jamrisko, M., \& Saraiva, C. (2018). These Are the World's Most Miserable Economies. Bloomberg. . Retrieved from https://www.bloomberg.com/news/articles/2018-02-14/most-miserableeconomies-of-2018-stay-haunted-by-inflation-beast [in English].

Kenneth, E.H. (2004). Legal, Social, and Ethical Issues of the Internet [Electronic resource]. Retrieved from https://www.oreilly.com/library/view/handbook-ofinformation/9780471648314/28_chapter-17.html [in English].

Latulippe, K., Hamel, C., \& Giroux, D. (2017). Social health inequalities and eHealth: a literature review with qualitative synthesis of theoretical and empirical studies. Journal of Medical Internet Research. 19, 4: 136. doi: 10.2196/jmir.6731 [in English]. 
Patterson, G. (2016). The Tech Literacy Imperative. Project Syndicate. Retrieved from https:// www.project-syndicate.org/commentary/tech-literacy-for-digital-natives-by-gavin-patterson-2016-01/russian?barrier=accesspaylog [in English].

Prensky, M. (2001). Digital Natives Digital Immigrants. MCB University Press, 9, 5. Retrieved from https://www.marcprensky.com/writing/Prensky\%20-\%20Digital\%20Natives,\%20Digital\%20Immigrants\%20-\%20Part1.pdf [in English].

Ragnedda, M., \& Muschert, G. (2017).The orizing Digital Divides. Routledge Advances in Sociology. Abingdon: Taylor \& Francis [in English].

Reilley, C.A. (2011). Teaching Wikipedia as a Mirrored Technology. First Monday, 16, 1. Retrieved from https://ojphi.org/ojs/index.php/fm/article/ view/2824/2746 [in English].

The Global Competitiveness Report 2014-2015. (2019). The World Economic Forum. Retrieved from http://reports.weforum.org/global-competitiveness-report-2014-2015/ [in English].

Top 15 Best Global Brands Ranking (2000-2018). (2019). Retrieved from https://www.youtube. $\mathrm{com} /$ watch?v=BQovQUga0VE [in English].

Vartanova, E., \& Smirnova, O. (2009). Digital Divide as a Problem of Information Society. World of Media :Yearbook of Russian Media and Journalism Studies, 5-21 [in English].

Whyte, C. (2018). Crossing the Digital Divide: Monism, Dualism and the Reason Collective Action is Critical for Cyber Theory Production. Politics and Governance, 6, 2. doi: 10.17645/pag. v6i2.1338 [in English].

Yun, Ch. (2015). The Technologization of Politics: The Internet and the Electronic Citizen. Undergraduate Awards, 2. Retrieved from https://ir.lib.uwo.ca/ungradawards_2015/2 [in English].

Zacher, L.W. (2017). Technologization of Man and Marketization of His Activities and Culture of the Future. In L.W. Zacher (Ed), Technology, Society and Sustainability (pp. 27-38). Springer, Cham [in English]. 
UDC 004.77:316.77]:316.34-028.63(477)

\author{
Tetyana Myskevych, \\ Junior Research Associate, \\ the National Law Library \\ of the National Library of Ukraine \\ named after $V$. I. Vernadsky \\ (Kyiv, Ukraine) \\ e-mail: Mizkevich83@gmail.com
}

ORCID: https://orcid.org/0000-0002-2324-6869

\title{
DIGITAL INEQUALITY IN MODERN SOCIETY: UKRAINIAN DIMENSION OF GLOBAL TRENDS
}

Nowadays, the pervasive informatization becomes a precondition for further human development. Although, its macrosocial reformative effect is connected not only with obtaining new advantages and abilities in different spheres of people's life, but also with a bunch of modernization risks and threats for the sustainable human society development. The debatable process of the global informatization actualizes the task of comprehension of one of the world's major and key problems - the phenomenon of the digital inequality.

The article covers the observation of the specific aspects of the digital inequality deployment in the modern society as well as determination of the actual complex estimate of the problem significance for Ukraine. Digital inequality is investigated as a dynamic threat which simultaneously propagates on the global, regional and local levels. The main factors of shift of balance are defined together with its current measures.

In as much as the digital inequality phenomenon is complex and it has many aspects this study is based on a complex approach which takes into account the evolution of the digital inequality and identification of two stages of its deployment. For the purpose of determining the situation with digital inequality in Ukraine statistical investigations and monitoring methods were applied. This allowed determining the current status of the digital inequality and the dynamics of the key indexes in Ukraine regarding the level of development of the informational society in the world's ranks data.

The research findings made possible to conclude that Ukraine stays in the role of relatively hind ward country with a «catch-up» informatization inside of which both stages of digital inequality deployment take place simultaneously. The main steps of state policy implementation intended for minimization of destructive occurrences of digital inequality have been suggested.

Key words: digital inequality, Global digital divide, levels of digital inequality, drive factors of digital divide, informatization, digital divide in Ukraine, information and communication technology. 